Original Research Article

\title{
Drug utilization study and adverse drug reactions of oral anti diabetics among type 2 diabetes mellitus patients in tertiary care hospital
}

\author{
Sahana M. Mogali, Aruna Bhushan*, Jagadishchandra S. Ratnakar
}

Department of Pharmacology, Belagavi Institute of Medical Sciences, Belagavi, Karnataka, India

Received: 18 January 2019 Accepted: 27 February 2019

*Correspondence to:

Dr. Aruna Bhushan,

Email: arunamarina@ yahoo.co.in

Copyright: (C) the author(s), publisher and licensee Medip Academy. This is an openaccess article distributed under the terms of the Creative Commons Attribution NonCommercial License, which permits unrestricted noncommercial use, distribution, and reproduction in any medium, provided the original work is properly cited.

\begin{abstract}
Background: The aim was to evaluate the drug utilization pattern of oral antidiabetic drugs in type 2 diabetes mellitus outpatients and monitor adverse drug reactions (ADRs) associated with oral antidiabetic drugs.

Methods: A retrospective observational study was carried out by collecting the data of type 2 diabetes mellitus patients visiting outpatient department of noncommunicable disease clinic of a tertiary care hospital for a period of one year. The data of demographic, drug utilization pattern and adverse drug reactions of patients on oral antidiabetic drugs was collected and entered in a proforma.

Results: Total number of patients in this study were 39 out of which $21(53.85 \%)$ patients were females and $18(46.15 \%)$ patients were males. Majority of patients were in the age group 51-70 years (66.6\%). Metformin was the most commonly prescribed drug $76.9 \%$ followed by Glibenclamide $17.9 \%$. About $7.7 \%$ of patients who were taking oral antidiabetic drugs later switched over to insulin as their blood glucose levels were not controlled. Out of $18(46.15 \%)$ patients, hypertension $(38.5 \%)$ was the most common comorbid condition and a concomitant drug was prescribed was amlodipine $25.6 \%$. Among all the adverse drug reactions observed, diarrhoea was the most common adverse drug reaction reported $76.9 \%$.

Conclusions: Metformin was the most commonly used oral antidiabetic drug. Diarrhoea was the common adverse drug reaction reported.
\end{abstract}

Keywords: Adverse drug reactions, Drug utilisation, Oral antidiabetic drugs

\section{INTRODUCTION}

Diabetes Mellitus refers to group of metabolic disorders that share the phenotype of hyperglycemia and altered metabolism of carbohydrates, lipids and proteins. ${ }^{1}$ Factors contributing to hyperglycaemia include reduced insulin secretion, decreased glucose utilization and increased glucose production. Major complications of diabetes are cardiovascular diseases, nephropathy, neuropathy and retinopathy. It has been predicted that by the year 2025 , in India the prevalence of diabetes in adults will be $6 \%{ }^{2}$
Routine management of diabetes mellitus includes glycaemic control by diet, regular exercises, insulin therapy and oral antidiabetic drugs.

There are different classes of anti-diabetic agents, and their selection depends on the nature of diabetes, age and complications, as well as other factors. Oral antidiabetic agents taken orally lower glucose levels in the blood. They are commonly used in the treatment of type 2 diabetes mellitus. The therapeutic combination in type 2 may include insulin, not necessarily because oral agents have 
failed completely, but in search of a desired combination of effects.

Drug Utilization Review (DUR) is a process used to assess the appropriateness of drug therapy by evaluating the data on drug use in a given healthcare environment against predetermined criteria and standards. ${ }^{3}$ Drug utilization study is important to monitor and improve the prescribing pattern of physician. Since polypharmacy in the treatment of diabetes mellitus is affecting the quality of life of patients by producing adverse drug reactions. Several drug utilization studies on antidiabetic drugs are periodically conducted across the world, including India to identify irrational prescribing. ${ }^{4-7}$ With this background, this study was conducted to evaluate the drug utilization pattern and to monitor the adverse drug reactions of oral antidiabetic drugs in this tertiary care hospital.

\section{METHODS}

The retrospective observational study was conducted over a period of one year from July 2017 to July 2018 in outpatient department of noncommunicable disease clinic at BIMS, tertiary care hospital Belagavi. After obtaining approval and clearance from institutional ethics committee the study was carried out.

All type 2 diabetes mellitus patients aged more than 18 years of both sex with or without comorbid condition were included in this study. All the patients who were included, their case record with detailed data was collected using data extraction format. The relevant demographic data, drug utilization pattern and adverse drug reactions of patients on oral anti-diabetic agents were Collected and entered in a specially designed proforma. The data was analyzed statistically and results were expressed in numbers.

\section{RESULTS}

The total number of patients in this study were 39 , out of which 21 patients $(53.85 \%)$ were females and 18 patients $(46.15 \%)$ were males and majority of patients were in the age group 51-70 years $(66.6 \%)$ is shown in the Figure 1. Metformin was the most commonly prescribed drug as monotherapy and with combination $76.9 \%$, followed by glibenclamide $17.9 \%$ depicted in the Figure 2.

The 3 patients $(7.7 \%)$ were initially on oral antidiabetic drugs, since their blood glucose levels were not controlled, they were switched over to regular insulin preparations. Most of the patients about $25(64.1 \%)$ were prescribed with combination of two drugs metformin or glibenclamide with voglibose.

Comorbid conditions were found in 18 patients $(46.15 \%)$ with most common being hypertension $(38.5 \%)$ is shown in the Table 1 . Three patients $(7.7 \%)$ had more than one comorbid condition along with hypertension they were also diagnosed with dyslipidemia, hypothyroidism and stroke. Amlodipine was the most common concomitant drug prescribed $25.6 \%$ Table 2. Among all the adverse drug reactions observed, diarrhoea was the common adverse drug reaction reported $76.9 \%$ is shown in Table 3 .

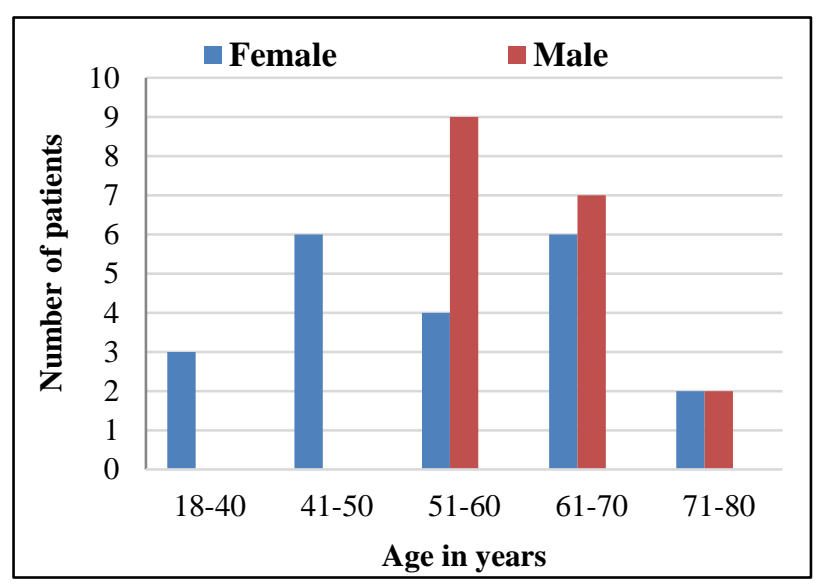

Figure 1: Age and sex wise distribution.

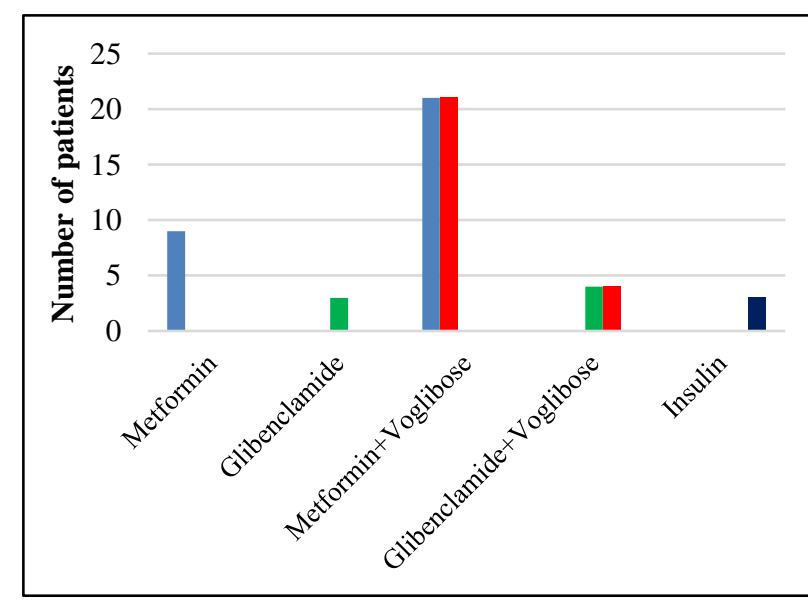

Figure 2: Anti-diabetic utilization pattern in type 2 diabetic patients.

Table 1: Comorbid conditions in type II DM patients.

\begin{tabular}{|ll|}
\hline Associated disease & Number of patients (\%) \\
\hline Hypertension & $15(38.5)$ \\
\hline Dyslipidaemia & $1(2.6)$ \\
\hline Hypothyroidism & $1(2.6)$ \\
\hline Stroke & $1(2.6)$ \\
\hline
\end{tabular}

Table 2: Concomitant drugs along with anti-diabetic agents.

\begin{tabular}{|ll|}
\hline Drugs & Number of patients $(\%)$ \\
\hline Amlodipine & $10(25.6)$ \\
\hline Atenolol & $2(5.1)$ \\
\hline Losartan & $2(5.1)$ \\
\hline Statins & $2(5.1)$ \\
\hline Aspirin & $1(2.6)$ \\
\hline Clopidogrel & $1(2.6)$ \\
\hline
\end{tabular}


Table 3: Adverse drug reactions (ADRs) to anti-diabetics.

\begin{tabular}{|ll|}
\hline ADR & Number of patients (\%) \\
\hline Diarrhoea & $30(76.9)$ \\
\hline Giddiness & $3(7.7)$ \\
\hline Abdominal discomfort & $2(5.1)$ \\
\hline Itching & $2(5.1)$ \\
\hline Allergic reaction & $1(2.6)$ \\
\hline Gastric irritation & $1(2.6)$ \\
\hline
\end{tabular}

\section{DISCUSSION}

Diabetes mellitus is a group of metabolic disorder with high levels of blood sugar over a prolonged period. Type $2 \mathrm{DM}$ also referred as non insulin dependent diabetes mellitus which manifest with insulin resistance where the cells fail to respond to insulin properly. Later as disease progress, there may be lack of insulin.

In this study population, out of 39 patients female patients were more $53.85 \%$. Similar studies conducted in Ahmedabad and Kerala showed neither female nor male preponderance. ${ }^{7,8}$ But few studies showed male preponderance..$^{5,6,9}$

Majority of our patients were in the age group of 51-70 since type $2 \mathrm{DM}$ is adult-onset diabetes. Similar findings were obtained from other studies also. ${ }^{4-6,9,10}$

In the present study, most commonly used oral antidiabetics drug as monotherapy was metformin $76.9 \%$, as metformin is safe and cost effective, euglycaemic, ability to prevent macrovascular complications. Similar findings were seen in other studies.,11,12 Among sulfonylureas, Glibenclamide was most commonly used $17.9 \%$. Voglibose an $\alpha$-glucosidase inhibitor in combination with other oral antidiabetic drugs was prescribed in $64.1 \%$ patients. In this study the reason for prescription and choice of oral antidiabetics is due to availability of medicine in this hospital pharmacy and also due to cost factor.

Hypertension was the commonest comorbid condition $38.5 \%$ seen in this study, findings were similar to the studies conducted in Ahmedabad and Odisha., ${ }^{9,11,13-15}$ Along with hypertension, three patients had other comorbid conditions like dyslipidaemia, hypothyroidism and stroke. Associated disease may be due to genetic variants in the gene encoding angiotensinogen, adrenomedullin, apolioprotein and $\alpha$-adducin. Besides genetic aspects, diet and physical activity are very important factors for onset of these diseases. ${ }^{16}$ Amlodipine was the most common concomitant drug used 25.6\%. 39 ADRs were reported during this study. Diarrhoea was the most common ADR observed in 30 patients. Okayasu $\mathrm{S}$ et al also have reported similar findings in their study and diarrhea as adverse effect was the most frequent initial symptom due to lactic acidosis. ${ }^{17}$

\section{CONCLUSION}

Drug utilization study is a popular tool in evaluation of health systems and to encourage rational use of drugs. Periodical evaluation of prescription will help in improvement of proper drug use, avoid unnecessary use of multiple drugs, drug interactions and adverse reaction thus, providing a good health care economically. Metformin and other drugs prescribed were in brand names and appropriate and were procured from hospital pharmacy. Prescribing trend is changing to two drug combination therapy due to thorough knowledge of prescribers. Limitation of our study was sample size which restricted the generalization of the findings.

\section{ACKNOWLEDGEMENTS}

Authors would like to thank their director and head of the Department of Pharmacology and staff of the institution for their support.

\section{Funding: No funding sources}

Conflict of interest: None declared

Ethical approval: The study was approved by the Institutional Ethics Committee

\section{REFERENCES}

1. Fauci AS, Braunwald E, Kasper DL, Hauser SL, Longo DL, Longo DL, et al. In: Alvin C Powers. Diabetes mellitus: diagnosis, classification, and pathophysiology. Harrison's Principles of Internal Medicine. 19th ed. USA: McGraw Hill; 2017:23982407.

2. King H, Aubert RE, Herman WH. Global burden of diabetes, 1995-2025: prevalence, numerical estimates and projections. Diabetes care. 1998;21(9):1414-31.

3. Adhikari AK, Vidyasagar G, Rathore DS, Balaram G, Bhakti G. Drug utilization review of antidiabetic drugs in patients of a tertiary care hospital of India. Indian J Hosp Pharm. 2011;48(2):32-4.

4. Alex SM, Srelekshmi BS, Smitha S, Jiji KN, Menon AS, Uma Devi P. Drug utilization pattern of antidiabetic drugs among diabetic outpatients in tertiary care hospital. Asian J Pharm Clin Res. 2015;8(2):144-6.

5. Upadhyay DK, Palaian S, Ravi Shankar P, Mishra P, Sah AK. Prescribing pattern in diabetic outpatients in tertiary care teaching hospital in Nepal. J Clin Diagn Res. 2007;3:248-55.

6. Vengurlekar S, Shukla P, Patidar P, Bafaa R, Jain S. Prescribing pattern of antidiabetic drugs in Indore city hospital. Indian J Pharm Sci. 2008;70(5):637-40.

7. Dare DJ, Dikshit RK, Gandhi AM. Utilization of some newer oral antidiabetic agents in a tertiary care hospital. Natl J Physiol Pharm Pharmacol. 2012;2(2):146-51.

8. Kannan, Arshad, Kumar S. A study on drug utilization of oral hypoglycemic agents in type-2 diabetic patients. Asian J Pharm Clin Res. 2011;4:60-4. 
9. Patel B, Oza B, Patel KP, Malhotra SD, Patel VJ. Pattern of antidiabetic drugs use in type 2 diabetic patients in a medicine outpatient clinic of a tertiary care teaching hospital. Int $\mathrm{J}$ Basic Clin Pharmacol. 2013;2:485-91.

10. Sivasankari V, Manivannan E, Priyadarsini SP. Drug utilization pattern of anti-diabetic drugs in a rural area of Tamil Nadu, South India - A prospective, observational study. Int J Pharm Bio Sci. 2013;4:5149.

11. Agarwal R, Rath B, Saha K, Mohaptra S. Drug utilization pattern of antidiabetic agents in a tertiary care hospital of western Odisha, India. Int J Basic Clin Pharmacol. 2016;5(5):2222-6.

12. Thiyagu R, Arulmani R, Narmadha T, Ramlakshami S, Siraj ST. Drug Use Pattern Study of Antidiabetics in Outpatient Setting of a Secondary Care Hospital. Indian J Hosp Pharm. 2008;45(6):176-9.

13. Jenny L, Arifulla M, Sreedharan J, Muttappallymyalil J, Das R. Age and gender-based utilization pattern of antidiabetic drugs in Ajman, UAE. Malay J Pharm Sci. 2012;10(1):79-85.

14. John LJ, Arifulla M, Sreedharan J, Muttappallymyalil J, Das R, John J, et al. Age and gender-based utilization pattern of antidiabetic drugs in Ajman,
United Arab Emirates. Malay J Pharm Sci. 2012;10:79-85

15. Alam MS, Aqil M, Qadry SA, Kapur P, Pillai KK Utilization pattern of oral hypoglycemic agents for diabetes mellitus type 2 patients attending out-patient department at a University hospital in New Delhi. Pharmacol Pharm. 2014;5:636-45.

16. Cheung CY, Tso AW, Cheung BM, Xu A, Ong KL, Law LS, et al. Genetic variants associated with persistent central obesity and the metabolic syndrome in a 12-year longitudinal study. Eur J Endocrinol. 2011 Mar 1;164(3):381-8.

17. Okayasu S, Kitaichi K, Hori A, Suwa T, Horikawa Y, Yamamoto $\mathrm{M}$ et al. The evaluation of risk factors associated with adverse drug reactions by metformin in type 2 diabetes mellitus. Bio Pharm Bull 2012;35(6):933-7.

Cite this article as: Mogali SM, Aruna B, Ratnakar JS. Drug utilization study and adverse drug reactions of oral anti diabetics among type 2 diabetes mellitus patients in tertiary care hospital. Int $\mathrm{J}$ Basic Clin Pharmacol 2019;8:700-3. 